Article

\title{
Experimental and Theoretical Insights on Methylene Blue Removal from Wastewater Using an Adsorbent Obtained from the Residues of the Orange Industry
}

\author{
Stephanie Giraldo ${ }^{1}$, Irma Robles ${ }^{2}$, Luis A. Godínez ${ }^{2} \mathbb{1}$, Nancy Acelas ${ }^{1, *} \mathbb{C}$ and Elizabeth Flórez ${ }^{1, *}$ \\ 1 Grupo de Investigación Materiales con Impacto (Mat\&mpac), Facultad de Ciencias Básicas, \\ Universidad de Medellín, Carrera 87 No. 30-65, Medellín 050026, Colombia; stepha930925@hotmail.com \\ 2 Centro de Investigación y Desarrollo Tecnológico en Electroquímica S. C., Parque Tecnológico Querétaro, \\ Sanfandila, Pedro Escobedo 76703, Querétaro, Mexico; irobles@cideteq.mx (I.R.); \\ lgodinez@cideteq.mx (L.A.G.) \\ * Correspondence: nyacelas@udem.edu.co (N.A.); elflorez@udem.edu.co (E.F.)
}

check for updates

Citation: Giraldo, S.; Robles, I.; Godínez, L.A.; Acelas, N.; Flórez, E. Experimental and Theoretical Insights on Methylene Blue Removal from Wastewater Using an Adsorben Obtained from the Residues of the Orange Industry. Molecules 2021, 26, 4555. https://doi.org/10.3390/ molecules26154555

Academic Editor: João Valente Nabais

Received: 28 May 2021

Accepted: 13 June 2021

Published: 28 July 2021

Publisher's Note: MDPI stays neutral with regard to jurisdictional claims in published maps and institutional affiliations.

Copyright: (c) 2021 by the authors. Licensee MDPI, Basel, Switzerland. This article is an open access article distributed under the terms and conditions of the Creative Commons Attribution (CC BY) license (https:// creativecommons.org/licenses/by/ $4.0 /)$.

\begin{abstract}
Chemical and thermochemical transformations were performed on orange peel to obtain materials that were characterized and further tested to explore their potential as adsorbents for the removal of methylene blue $(\mathrm{MB})$ from aqueous solutions. The results show the high potential of some of these materials for $\mathrm{MB}$ adsorption not only due to the surface area of the resulting substrate but also to the chemistry of the corresponding surface functional groups. Fitting of the kinetic as well as the equilibrium experimental data to different models suggests that a variety of interactions are involved in MB adsorption. The overall capacities for these substrates (larger than $192.31 \mathrm{mg} \mathrm{g}^{-1}$ ) were found to compare well with those reported for activated carbon and other adsorbents of agro-industrial origin. According to these results and complementary with theoretical study using Density Functional Theory (DFT) approximations, it was found that the most important adsorption mechanisms of MB correspond to: (i) electrostatic interactions, (ii) H-bonding, and (iii) $\pi$ (MB) $-\pi$ (biochar) interactions. In view of these findings, it can be concluded that adsorbent materials obtained from orange peel, constitute a good alternative for the removal of MB dye from aqueous solutions.
\end{abstract}

Keywords: adsorption; dyes; orange peel; adsorption mechanism; DFT

\section{Introduction}

Contamination of water bodies by the continuous discharge of wastewater containing dyes from textile, paper, cosmetic and, pharmaceutical industries [1,2], have caused a deterioration of aquatic ecosystems and, methylene blue (MB) is one of the most harmful basic/cationic dyes, used for dyeing products such as wood, silk, and cotton [3-5].

Reducing the organic dye contaminations is of great importance due to the inherent toxicity of the dye molecules and because these compounds decrease light penetration within water, thus all of the photosynthetic processes are seriously affected. Therefore, several organic dye reduction techniques to remove the dye component from the wastewater have been developed. Adsorption compared to other treatment techniques, such as, chemical deposition, reverse osmosis, coagulation, and flocculation [6,7] has been identified as a superior technology due to its low cost, high efficiency, ease of operation, wide variety of available adsorbents which can be used repeatedly for many cycles and proves to be very cost-effective [8].

Adsorbents produced from agro-industrial wastes are considered as an interesting alternative due to their high accessibility, low production cost, high porosity, variety of surface functional groups, and high efficiency for dye removal [9-11]. In fact, it will help to solve the problem of agro-industrial waste disposal through the development of a circular economy with the efficient valorization of these wastes. 
In Colombia, citrus juice companies discard between 15 and 25 tons of orange peel (OP) where only a fraction is employed to extract pectin, limonene [12] and, biopolymers used in the food and pharmaceutical industry [13]. The remaining residue is frequently disposed without any further use. Chemical and physical modifications of OP allow one to design adsorbent materials for the efficient removal of organic contaminants, such as MB. For example, heat treatments at low temperatures allow one to obtain adsorbent materials rich in oxygenated functional groups [14] and low surface areas [15]; while the use of chemical activating agents allows for modification of both the surface area and the quantity and variety of surface functional groups. For example, $\mathrm{ZnCl}_{2}$ allows for generation of adsorbent materials with high surface area due to dehydration and elimination of the most volatile biomass components [16] while $\mathrm{H}_{3} \mathrm{PO}_{4}$ allows one to generate a surface rich in oxygenated functional groups [17], such as carboxylic, lactonic, and phenolic groups, which have been reported as active in the MB adsorption process. The combination of different biomass modification processes allows obtaining materials with varied physicochemical properties to be applied in the elimination of pollutants. Several authors have reported good adsorption properties for the material adsorbent produced from OP to remove $\mathrm{MB}$ from water with adsorption capacities ranging from 7.57 to $218 \mathrm{mg} \mathrm{g}^{-1}$ or thermally transformed materials and for chemically transformed materials [18-21]. These properties are comparable with the ones reported for commercial activated carbons, where the maximum adsorption capacities are from 45 to $195 \mathrm{mg} \mathrm{g}^{-1}$ [13,19,21-24].

The main drawback is that most of the studies are focused on determining adsorption capacities [25] and characterizing the process through the application of kinetic and isotherm models [26,27], and very few studies [28,29] have been reported where computational chemistry tools are also combined to understand the adsorption mechanism and the role of functional groups present in the materials used. For instance, in their study, Sellaoui et al. [29] found that the hydrogen and oxygen functionalities of biomass surface were the major in charge functional groups for dye adsorption. Density functional theory (DFT) has become a powerful and informative tool to: (i) assess the atomic understanding of the adsorption mechanism; (ii) achieve the design of a "functionalized" material to remove cationic dyes; and (iii) predict the feasibility of adsorption of a specific adsorbent targeting a particular adsorbate. The molecular understanding of these interactions and, the influence of $\mathrm{pH}$ on the $\mathrm{MB}$ removal process, are important parameters because it will allow the understanding of the adsorption mechanism and the optimization of the process conditions not only for dye removal, but for the subsequent regeneration of the adsorbent and eventually, for the design of other novel engineered adsorbent surfaces.

Thus, the novelty of the present work was the systematic transformation of biomass to produce adsorbent materials of different nature and, the characterization of the interactions between $\mathrm{MB}$ and the adsorbents by using the experimental data related with density functional theory (DFT) calculations.

\section{Methodology}

\subsection{Materials and Transformation Methods}

Figure 1 presents a summary of the different methods of orange peel transformations.

Orange peel (OP) for this study was collected after consuming orange juice. The residue was washed several times with distilled water and dried in an oven at $105^{\circ} \mathrm{C}$ for $12 \mathrm{~h}$. The material was then cut into small pieces, grounded (particle size $<0.420 \mathrm{~mm}$ ) and stored. OP biomass was modified by thermal, chemical, and thermochemical transformations. Initially, the OP biomass was transformed by heat treatment at different temperatures using an oven set at temperatures of $250,350,450$, and $550{ }^{\circ} \mathrm{C}$ for $30 \mathrm{~min}$. The resulting materials were labeled OP-250, OP-350, OP-450, and OP-550, respectively. Chemical transformation was performed using $\mathrm{ZnCl}_{2}$ and $\mathrm{H}_{3} \mathrm{PO}_{4}$. A known amount of OP was immersed in a $\mathrm{ZnCl}_{2}(3 \mathrm{M})$ solution for $24 \mathrm{~h}$ and then heated to a temperature of $105^{\circ} \mathrm{C}$ in an oven for $12 \mathrm{~h} \mathrm{[16].} \mathrm{The} \mathrm{material} \mathrm{thus} \mathrm{prepared} \mathrm{was} \mathrm{labeled} \mathrm{as} \mathrm{AZOP.} \mathrm{Different}$ OP samples were immersed in a solution of $\mathrm{H}_{3} \mathrm{PO}_{4}(0.6 \mathrm{M})$ for $2 \mathrm{~h}$ and then dried at $95{ }^{\circ} \mathrm{C}$ 
for $12 \mathrm{~h}$ [30]. This material was labeled as AHOP. Thermochemical activation on the other hand was performed using $\mathrm{ZnCl}_{2}$ and $\mathrm{H}_{3} \mathrm{PO}_{4}$. For activation with $\mathrm{ZnCl}_{2}$, the OP sample was impregnated with $\mathrm{ZnCl}_{2}(3 \mathrm{M})$ under constant stirring $(200 \mathrm{rpm})$ for $24 \mathrm{~h}$. One part was taken to a muffle furnace and calcinated at $550{ }^{\circ} \mathrm{C}$ (called AZOP-550) and the other part at $600{ }^{\circ} \mathrm{C}$ (called AZOP-600). The calcination process for both samples lasted $30 \mathrm{~min}$. Each sample was then immersed in an $\mathrm{HCl}$ solution (2 M) and stirred at $200 \mathrm{rpm}$ for $3 \mathrm{~h}$ followed by a washing stage with distilled water up until a neutral $\mathrm{pH}$ was obtained. For thermochemical activation with $\mathrm{H}_{3} \mathrm{PO}_{4}$, the same chemical transformation procedure was carried out. Then, the sample was taken to the muffle furnace where the sample was heated at $600{ }^{\circ} \mathrm{C}$ for $3 \mathrm{~h}$ under nitrogen flowing at $150 \mathrm{~cm}^{3} \mathrm{~min}^{-1}$. This material was labeled as AHOP-600. Finally, all of the activated materials were vacuum filtered, dried in an oven at $105{ }^{\circ} \mathrm{C}$ for $12 \mathrm{~h}$ and macerated to a particle-size $<0.420 \mathrm{~mm}$.

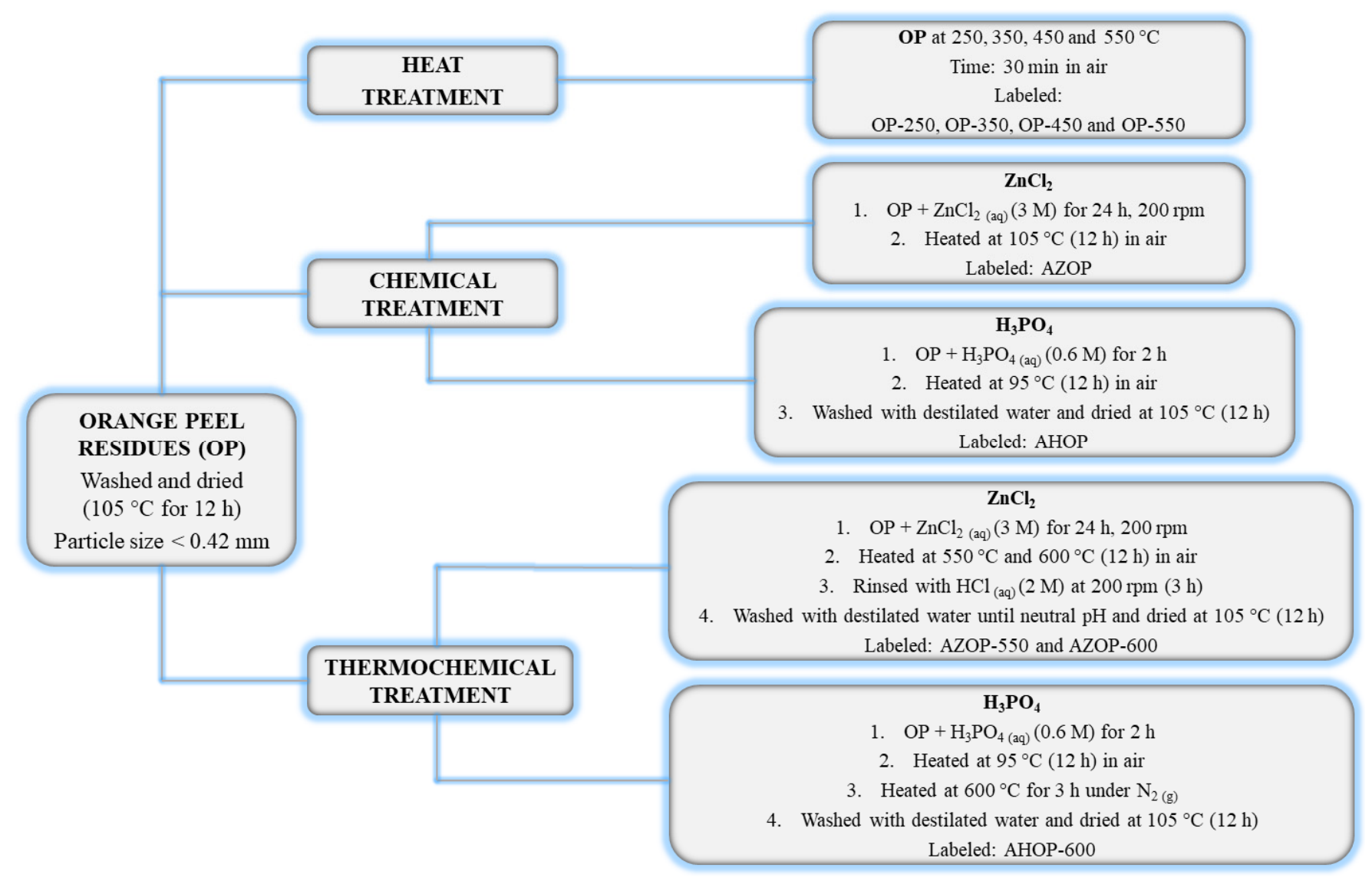

Figure 1. Orange peel transformation methods to obtain adsorbent materials.

\subsection{Physicochemical Characterization}

The physicochemical characterization of the materials was performed using different analysis techniques. In order to assess (OP) composition, the proximate analysis and elemental analysis were carried out. The surface area determination was performed by using the BET method (Brunauer, Emmett, and Teller) and the active functional groups were studied by Fourier transformed infrared spectroscopy (FT-IR) in the of 4000 to $450 \mathrm{~cm}^{-1}$ range using a Spectrum two-PerkinElmer with UATR. While the $\mathrm{pH}$ of zero point charge $\left(\mathrm{pH}_{\mathrm{PZC}}\right)$ was determined by the salt addition method [31] and, the acidic and basic surface functional groups of the materials were quantified using the method proposed by Boehm [32]. 


\subsection{Adsoption Tests}

\subsubsection{Batch Adsorption Studies}

In this study, the effects of $\mathrm{pH}$ and the adsorption time on adsorption performances were evaluated by using batch adsorption studies. Firstly, preliminary adsorption tests were performed to assess the performance of the different materials as follows: for each adsorbent material, a sample of $0.05 \mathrm{~g}$ was mixed in an Erlenmeyer flask with $50 \mathrm{~mL}$ of MB solutions with a concentration of $50 \mathrm{mg} \mathrm{L}^{-1}$ at natural $\mathrm{pH}(\sim 7.4)$. The solution was stirred (200 rpm) for $2 \mathrm{~h}$ and the remaining concentration of MB in solution was determined using the spectrophotometer (VIS-DR 3900) absorption response at $\lambda=665 \mathrm{~nm}$.

The MB removal percentage for each sample was calculated using Equation (1) and, the dye adsorption capacity of the materials was determined employing Equation (2).

$$
\begin{gathered}
\% R=\frac{C_{0}-C_{t}}{C_{0}} \times 100 \\
q_{t}=\frac{C_{0}-C_{t}}{w} \times V
\end{gathered}
$$

In these equations, $C_{0}\left(\mathrm{mg} \mathrm{L}^{-1}\right)$ corresponds to the initial concentration of $\mathrm{MB}$ in solution, $C_{t}\left(\mathrm{mg} \mathrm{L}^{-1}\right)$ corresponds to $\mathrm{MB}$ concentration at time $(\mathrm{t})$ and $q_{t}\left(\mathrm{mg} \mathrm{g}^{-1}\right)$ means the amount of $\mathrm{MB}$ adsorbed per $\mathrm{g}$ of adsorbent material at time $t, V(\mathrm{~L})$ is the volume of the solution and $w(\mathrm{~g})$ represents the mass of the adsorbent material. From these tests, the materials with the best adsorption performance were selected for the kinetic and isothermal adsorption analysis. To evaluate the influence of $\mathrm{pH}$ on $\mathrm{MB}$ adsorption, a MB solution of $100 \mathrm{mg} \mathrm{L}^{-1}$ was adjusted at $\mathrm{pH}$ values of $2,4,6,8$, and 10 by using either $\mathrm{NaOH}$ or $\mathrm{HCl}$ $(0.1 \mathrm{M})$ solutions and the adsorbent materials tests were OP, AZOP-550, and AHOP.

\subsubsection{Adsorption Isotherms and Kinetics}

Batch experiments were conducted to evaluate the rate and adsorption equilibrium phenomena related to MB adsorption on OP, AZOP-550, and AHOP. A stock solution of $1000 \mathrm{mgL}^{-1} \mathrm{MB}$ was prepared and, the varying concentration of $\mathrm{MB}(50,100,150,200$, and $250 \mathrm{mg} \mathrm{L}^{-1}$ ) was prepared from the stock solution. After that, $500 \mathrm{~mL}$ of each solution were mixed with $0.5 \mathrm{~g}$ of the adsorbent material at natural $\mathrm{pH}$ and $25^{\circ} \mathrm{C}$. The mixture was stirred at $200 \mathrm{rpm}$ with a rotating propeller and samples were taken at different times until the equilibrium conditions were reached. In order to eliminate dilution effects, it was verified in every experiment that the total subtracted volume did not exceeded $5 \%$ of the total volume [33].

All of the experimental data were adjusted to the pseudo-first, pseudo-second order, and the intra-particular diffusion kinetic models [34-36] following the equations shown in Table S1. The adsorption isotherm models used to fit the experimental data were Langmuir, Freunlich, Temkin, and Dubinin-Radush-Kevich models, which are presented in Table S2 [37-40].

\subsection{DFT Calculations}

The adsorption interactions between $\mathrm{MB}^{+}$and the functional groups of the adsorbent materials were characterized through quantum chemical calculations. All of the calculations were performed with the Gaussian09 software package [41] using the DFTB3LYP method with a basis set of $6-31+G(d, p)$. All of the geometry optimizations and the vibrational frequencies analyses were conducted by considering the solvent effect, which considers long-range implicit hydration by applying the integral equation formalism variant of the polarized continuum model (IEFPCM) [42]. The local minimum potential energy values for each structure were confirmed since imaginary frequencies did not occur. Simulations of adsorbent materials surfaces with different oxygenated functional groups 
were conducted based on the experimental results. The adsorption energy $\left(\mathrm{E}_{\mathrm{ads}}\right)$ of $\mathrm{MB}^{+}$ on the carbonaceous model was determined by using Equation (3):

$$
\mathrm{E}_{\mathrm{ads}}=\mathrm{E}_{(\mathrm{MB}+)-\text { surface }}-\left(\mathrm{E}_{(\mathrm{MB}+)}+\mathrm{E}_{\text {surface }}\right)
$$

where $\mathrm{E}_{(\mathrm{MB}+)-\text { surface }}$ is the total energy of the complex formed by $\mathrm{MB}^{+}$and the carbonaceous surface. $\mathrm{E}_{(\mathrm{MB}+)}$ corresponds to the total energy of the $\mathrm{MB}^{+}$molecule, and $\mathrm{E}_{\text {surface }}$ is the total energy of the carbonaceous model.

\section{Results and Discussion}

\subsection{Performance of Adsorbent Material on MB Removal: Preliminary Tests}

To assess which materials, have the best adsorption performance, preliminary MB adsorption experiments were carried out on all of the adsorbents (Figure 2).

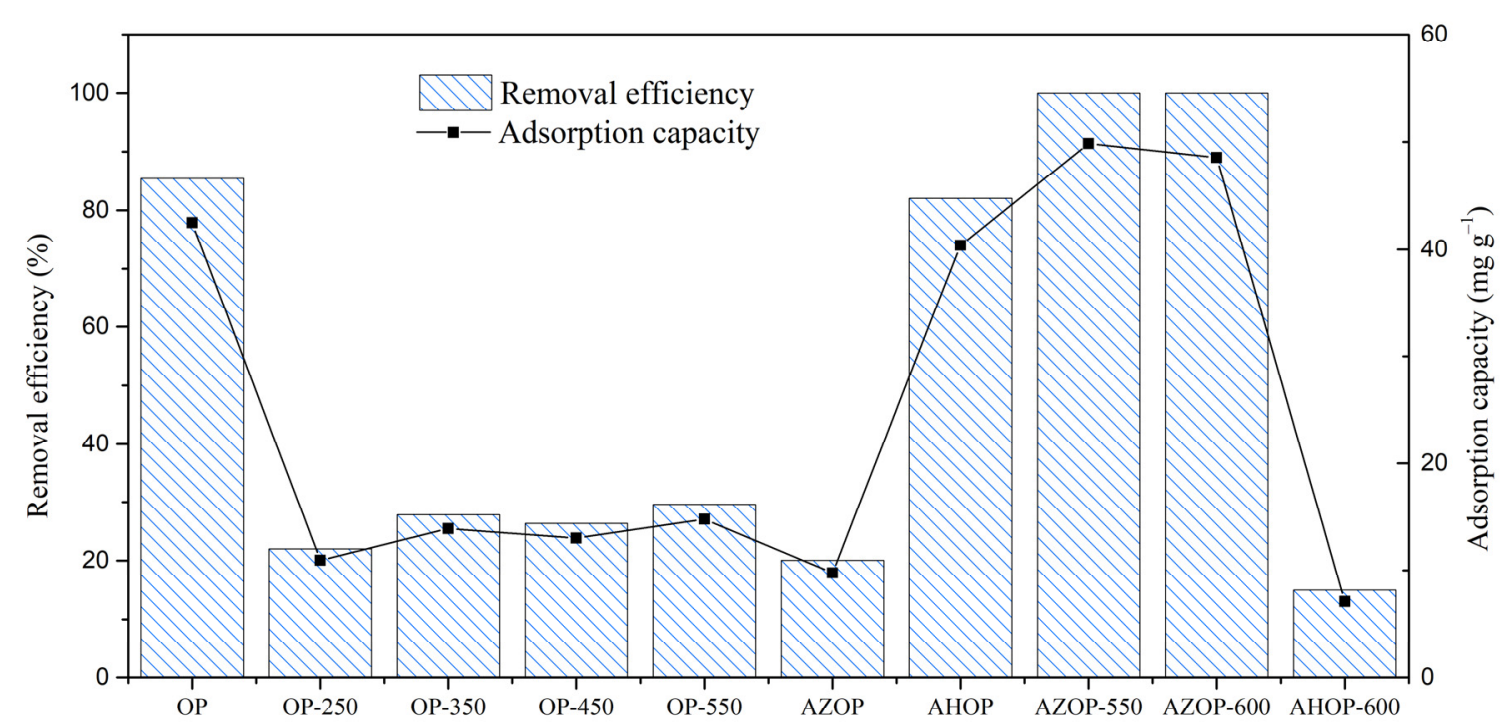

Figure 2. Comparison of MB removal efficiency and adsorption capacity for the different adsorbent materials.

For materials produced from thermal transformation of biomass (OP-250, OP-350, OP450, and OP-550), low removal capacities can be observed; moreover, there is no significant effect of biomass calcination temperature on the MB removal capacity, with values between 10.95 and $14.75 \mathrm{mg} \mathrm{g}^{-1}$ for OP-250 and OP-550, respectively.

For AZOP and AHOP materials produced by chemical transformation, it is evidenced that AHOP is five-times better in terms of removal efficiency and adsorption capacity respect to AZOP. However, when AHOP is compared with OP, very similar behavior can be evidenced. It should be that the addition of phosphoric acid, does not modify the oxygenated groups on the material surface, and therefore there is no change in the active groups for the adsorption of $\mathrm{MB}$ [17]. Whereas, when $\mathrm{ZnCl}_{2}$ is used, it is evident that there is a blockage of the active groups for the adsorption of $\mathrm{MB}$, which are present in OP.

The materials produced from the thermochemical modification showed that the materials modified with $\mathrm{ZnCl}_{2}$ are more efficient for the removal of $\mathrm{MB}$ in comparison to the ones activated with $\mathrm{H}_{3} \mathrm{PO}_{4}$. For AHOP- 600 only a removal of $16 \%$ of $\mathrm{MB}$ was observed. It is probably due to carbonization at high temperatures where surface functional groups that contain oxygen are released, limiting the number of active sites for MB adsorption [36]. While it has been reported that for carbonaceous materials activated with $\mathrm{ZnCl}_{2}$, high temperatures favor the formation of porosity generated by the dehydrating nature of this activating agent. With this observation, it is possible to deduce that MB adsorption occurs both by interaction with oxygenated functional groups and by porosity.

However, at this point, it is not possible to identify which of these two ways of adsorption is the one that contributes the most to the removal of MB by OP, and AZOP-550. 
For this, it was necessary to carry out a detailed textural analysis and chemical properties of the surface functional groups of these materials. Tables 1 and 2, show that for OP, AHOP, and AZOP-550, the materials with the highest MB removal efficiency there is a great difference in textural and chemical properties. For instance, OP and AHOP-600 are materials with low surface area ( 3 and $7 \mathrm{~m}^{2} \mathrm{~g}^{-1}$, respectively), while AZOP-550 is a material with very good porosity development $\left(1078 \mathrm{~m}^{2} \mathrm{~g}^{-1}\right)$. In this way, while the adsorption capacity of AZOP- 550 is about $15 \%$ larger than that of the other two materials (OP and AHOP) (see Figure 2), the corresponding surface area is about 350- and 180-times larger than those of OP and AHOP, respectively. It suggested that the interaction with functional groups is the main path of $\mathrm{MB}$ adsorption on these materials.

Table 1. Textural properties of the adsorbent materials under study.

\begin{tabular}{ccc}
\hline Material & Surface Area BET $\left(\mathbf{m}^{\mathbf{2}} \mathbf{g}^{-\mathbf{1}}\right)$ & Pore Volume $\left(\mathbf{c m}^{\mathbf{3}} \mathbf{g}^{-\mathbf{1}}\right)$ \\
\hline OP & 3.098 & 0.0013 \\
AHOP & 7.0142 & 0.0030 \\
AZOP-550 & 1078.56 & 0.5205 \\
\hline
\end{tabular}

Table 2. Content of surface chemical groups for the adsorbent materials under study.

\begin{tabular}{|c|c|c|c|c|c|c|}
\hline Material & $\begin{array}{l}\text { Carboxylic Group } \\
\quad\left(\mathrm{mmol} \mathrm{g}^{-1}\right)\end{array}$ & $\begin{array}{l}\text { Lactone Group } \\
\left(\mathrm{mmol} \mathrm{g}^{-1}\right)\end{array}$ & $\begin{array}{l}\text { Phenol Group } \\
\left(\mathrm{mmol} \mathrm{g}^{-1}\right)\end{array}$ & $\begin{array}{l}\text { Total Acid Sites } \\
\quad\left(\mathrm{mmol} \mathrm{g}^{-1}\right)\end{array}$ & $\begin{array}{l}\text { Total Basic Sites } \\
\quad\left(\mathrm{mmol} \mathrm{g}^{-1}\right)\end{array}$ & $\mathrm{pH}{ }_{(\mathrm{PZC})}$ \\
\hline OP & 0.650 & 0.925 & 0.200 & 1.774 & 0.000 & $3.5 \pm 0.08$ \\
\hline AHOP & 0.925 & 1.325 & - & 2.250 & 0.125 & $3.4 \pm 0.11$ \\
\hline AZOP-550 & 0.775 & 0.150 & 0.050 & 0.975 & 0.225 & $6.3 \pm 0.03$ \\
\hline
\end{tabular}

The effect of OP treatment on surface morphology (area and pore volume) should therefore be coupled to chemical changes on the surface functional groups that define MBadsorbent surface intermolecular interactions and therefore, the adsorption capacity of the materials. Figure 3 shows the FTIR spectra for OP, AHOP, and AZOP-550 adsorbents. While $\mathrm{OP}$ and AHOP show very similar spectra, the IR response for AZOP-550 is characterized by noticeable changes that are related to the degradation of functional groups and breaking of chemical bonds due to the high temperature of thermochemical process [43]. The bands in OP and AHOP show a signal at $3330 \mathrm{~cm}^{-1}$ that is related to the $\mathrm{O}-\mathrm{H}$ stretch mode of the hemicellulose and the signal at $2921 \mathrm{~cm}^{-1}$ that is associated with the $\mathrm{C}-\mathrm{H}$ elongation vibrations of lignin. The presence of $\mathrm{C}=\mathrm{O}$ at $1730 \mathrm{~cm}^{-1}$ is attributed to the ketone or aldehyde groups of hemicellulose and the signal located at $1641 \mathrm{~cm}^{-1}$ is related to carboxylic acid moieties. The band at $1515 \mathrm{~cm}^{-1}$, is associated to the vibration of the lignin aromatic ring, the signal at $1360 \mathrm{~cm}^{-1}$ is attributed to the stretching of the $\mathrm{C}-\mathrm{O}$ bonds of carboxylic acids present in cellulose, hemicellulose, and lignin groups and the peak around $1019 \mathrm{~cm}^{-1}$ may be related to the elongation of the vibration of $\mathrm{C}-\mathrm{O}$ bonds in phenols, ethers, and alcohols [23,43]. In the case of the spectrum for the thermochemically modified material, AZOP-550, the signals at 3640,1693,1573, 1165, and $876 \mathrm{~cm}^{-1}$ are related to the presence of $\mathrm{O}-\mathrm{H}, \mathrm{C}=\mathrm{O}, \mathrm{C}=\mathrm{C}$, bending of the $\mathrm{C}-\mathrm{C}-\mathrm{C}$, and the $\mathrm{C}-\mathrm{O}[23,44,45]$.

From Table 2, it can be observed that $\mathrm{OP}$ and AHOP are the materials with the highest amount of oxygenated functional groups, being 1.8- and 2.3-times higher with respect to AZOP-500, respectively.

The reduction of the total number of acidic groups (lactone and phenol groups) on the surface of AZOP-550, can be explained by the decomposition reactions of the cellulose, hemicellulose, and pectin - the main components of the OP biomass [43]. The larger concentration of acidic surface functional groups on OP and AHOP should be playing an important role in the selectivity and adsorption capacity for $\mathrm{MB}$ removal [46]. In these cases, there is less surface adsorption area than that of AZOP-550, but there is a larger density of acidic groups that, depending on the protonation state, should explain the behavior of 
adsorption interaction sites. Therefore, depending on the $\mathrm{pH}$, different types of interactions take place between $\mathrm{MB}$ and the adsorbent materials.

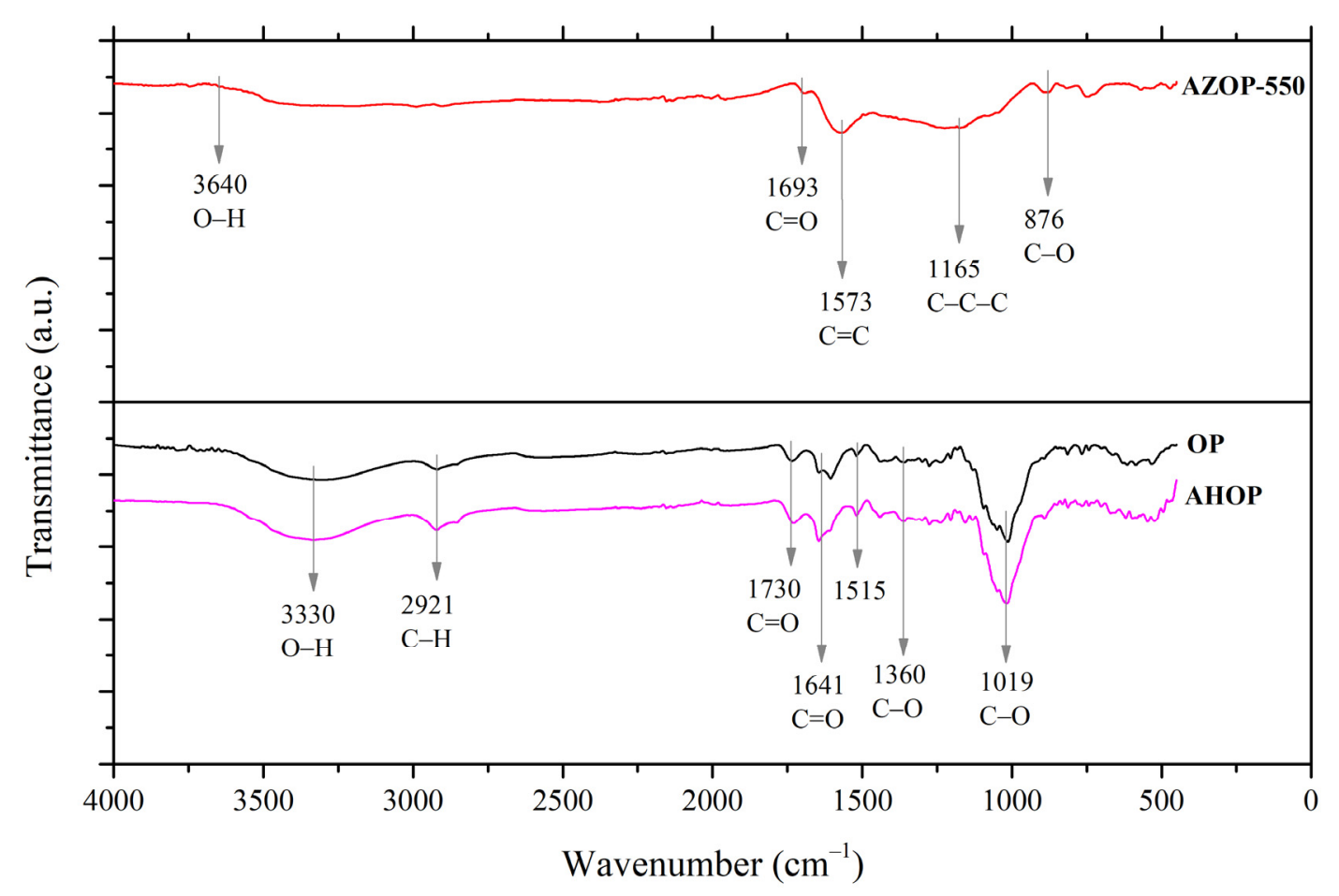

Figure 3. FTIR Spectra of OP, AHOP, and AZOP-550 adsorbents.

\section{2. $p H$ Effect on $M B$ Adsorption}

The $\mathrm{pH}$ value of the solution is an important parameter to control the adsorption process, since it may affect MB adsorption by changing the surface charge of the adsorbents and ionization behavior of adsorbents and dye [47]. Figure 4 shows the influence of $\mathrm{pH}$ on $\mathrm{MB}$ adsorption for OP, AHOP, and AZOP-550. At $\mathrm{pH}$ 2, the MB removal efficiency is lower for OP and AHOP, than for AZOP-550. At $\mathrm{pH}$ values higher than 4, MB removal increases for OP and AHOP and remains roughly constant for the AZOP-550 material. These results suggest that there is a common $\mathrm{pH}$ dependence for $\mathrm{OP}$ and AHOP that is not observed for AZOP-550. To understand the $\mathrm{pH}$ influence, it is necessary considering the $\mathrm{pH}_{(\mathrm{PZC})}$ of the adsorbents and the $\mathrm{pK}_{\mathrm{a}}$ (3.8) for $\mathrm{MB}$ [48]. For MB, $\mathrm{pH}$ values above 3.8, the cationic species are the preponderant $\mathrm{MB}$ species in the solutions [49]. For adsorbents, Table 2 shows that OP and AHOP have $\mathrm{pH}_{(\mathrm{PZC})}$ values of 3.5 and 3.4, respectively, while AZOP has a value of 6.3 (see Figure S2 from Supplementary Materials). Similar observations have been reported in the literature, where $\mathrm{M}$. Boumediene et al. [50] obtained a $\mathrm{pH}_{(\mathrm{PZC})}$ of 3.8 for orange peel without any transformation and A. Guediri et al. [51] transformed the orange peel using $\mathrm{H}_{3} \mathrm{PO}_{4}$ and obtained a $\mathrm{pH}_{(\mathrm{PZC})}$ of 3.34. This observation suggests that at a $\mathrm{pH}$ value of 2, $\mathrm{OP}, \mathrm{AHOP}$, and $\mathrm{MB}$ are positively charged and therefore the low dye removal percentages.

At $\mathrm{pH}$ values above the $\mathrm{pH}_{(\mathrm{PZC})}$ the adsorbent materials are negatively charged, favoring the cationic $\mathrm{MB}$ adsorption through electrostatic interactions. On the other hand, the $\mathrm{pH}$ does not have a significant effect for MB adsorption over AZOP-550, indicating that for the AZOP-550 material the high surface area and porosity are the main factors that control the MB adsorption process. 


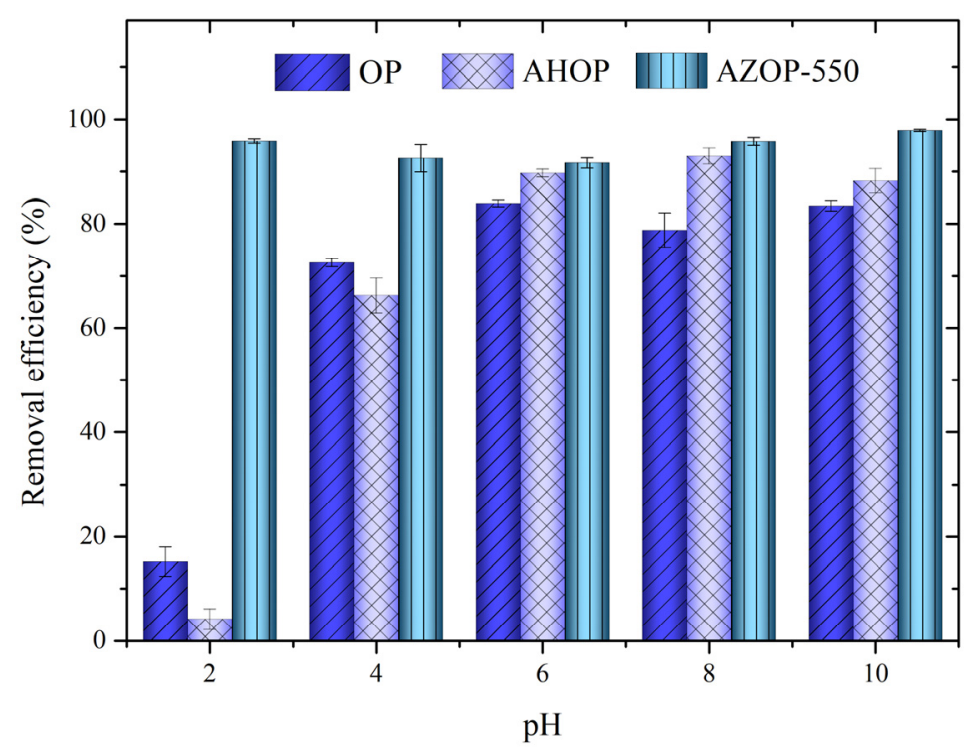

Figure 4. Effect of $\mathrm{pH}$ in the $\mathrm{MB}$ adsorption for the different substrates under study.

\subsection{Adsorption Kinetics}

Table S4 shows the kinetic parameters obtained from the fitting of the experimental data to the pseudo-first, pseudo-second order, and to the intra-particular diffusion models. The results show values of $\mathrm{R}^{2}=0.999$ for the pseudo-second order indicating that this model is a good representation of the MB adsorption process. Since this model considers the dependence of the adsorption rate on two concentrations, it can be assumed that chemisorption is the controlling step of the MB adsorption process over OP, AHOP, and AZOP-550.

To identify the reaction adsorption pathways and mechanisms that operate in these processes, the intra-particle diffusion model was employed. Table S4 shows a good fit to this model for MB removal on OP, AHOP, and AZOP-550, where the values of $\mathrm{k}_{1 \mathrm{~d}}$ are larger than the ones of $\mathrm{k}_{2 \mathrm{~d}}$, suggesting that surface adsorption is faster than the adsorption inside the pores. $C_{2}$ values are larger than the values of $C_{1}$, indicate that the contribution of adsorption on the surface when compared to that taking place in the pores is more important. These results are consistent with reports of $\mathrm{MB}$ removal using different adsorbents produce from biomass [24,50,51]. It is evident that MB adsorption on all of the adsorbent materials is a complex process involving multiple mechanisms (adsorption on the surface and diffusion within the pores of the adsorbent) for which the analysis of equilibrium adsorption data could shed some light.

\subsection{Adsorption Isotherms}

Four isotherm models were employed to assess the adsorption of MB on the adsorbent materials at equilibrium. According to the $\mathrm{R}^{2}$ values (Table 3), all of the models fitted the experimental data very well indicating a complex adsorption equilibrium process for all materials that partially follows the mechanisms that define the models under consideration. From Table $3, R_{L}$ value for all adsorbent materials falls in the range $0<R_{L}<1$ suggesting that the adsorption process is in all cases favorable. Fitting of the experimental data to the Langmuir adsorption model also reveals that the maximum adsorption capacities $\left(Q_{m}\right)$ for OP, AHOP, and AZOP-550, correspond to 192.31, 277.78, and $232.56 \mathrm{mg} \mathrm{g}^{-1}$, respectively. The fact that $\left(Q_{m}\right)$ is in the same order of magnitude for the three adsorbent materials, that is, a similar active adsorption surface area, is consistent with a picture of relatively low area and optimized MB adsorption chemical surface structure for OP and AHOP, and a large surface and poorly chemically structured surface for AZOP-550 (see Figure S4 from Supplementary Materials). 
Table 3. Parameters for the different isotherm adsorption models for the adsorption of MB on OP, AZOP-550, and AHOP.

\begin{tabular}{|c|c|c|c|}
\hline Material & OP & AHOP & AZOP-550 \\
\hline \multicolumn{4}{|c|}{ Langmuir } \\
\hline$Q_{m}\left(\mathrm{mg} \mathrm{g}^{-1}\right)$ & 192.31 & 277.78 & 232.56 \\
\hline $\mathrm{K}_{\mathrm{L}}\left(\mathrm{L} \mathrm{mg^{-1 }}\right)$ & 0.03 & 0.02 & 0.54 \\
\hline $\mathbf{R}_{\mathrm{L}}$ & $0.40-0.11$ & $0.48-0.16$ & $0.4-0.01$ \\
\hline $\mathbf{R}^{2}$ & 0.97 & 0.98 & 1.00 \\
\hline \multicolumn{4}{|c|}{ Freundlich } \\
\hline $\mathrm{K}_{\mathrm{F}}\left(\mathrm{mg} \mathrm{g}^{-1}\right)$ & 14.17 & 16.24 & 83.60 \\
\hline n & 1.86 & 1.87 & 3.03 \\
\hline $\mathbf{R}^{2}$ & 0.85 & 0.98 & 0.73 \\
\hline \multicolumn{4}{|c|}{ Temkin } \\
\hline $\mathrm{K}_{\mathrm{T}}\left(\mathrm{Lg}^{-1}\right)$ & 0.31 & 4.39 & 9.12 \\
\hline $\mathrm{b}\left(\mathrm{kJ} \mathrm{mol} \mathrm{mol}^{-1}\right)$ & 0.06 & 0.04 & 0.06 \\
\hline $\mathbf{R}^{2}$ & 0.96 & 0.98 & 0.89 \\
\hline \multicolumn{4}{|c|}{ Dubinin-Radushkevich } \\
\hline $\mathrm{K}_{\mathrm{DR}}\left(\mathrm{mol}^{2} \mathrm{~kJ}^{-2}\right)$ & 20.39 & 18.83 & 0.31 \\
\hline $\mathrm{q}_{\mathrm{s}}\left(\mathrm{mg} \mathrm{g}^{-1}\right)$ & 134 & 166 & 206 \\
\hline $\mathrm{E}\left(\mathrm{KJ} \mathrm{mol}^{-1}\right)$ & 0.16 & 0.16 & 1.28 \\
\hline $\mathbf{R}^{2}$ & 0.98 & 0.86 & 0.94 \\
\hline
\end{tabular}

As can be seen in Table 3, the fitting of the experimental adsorption data to the Freundlich model also suggests that $\mathrm{MB}$ adsorption takes place by a mixture of interactions with the different functional groups of the adsorbent surface; involving as expected, a variety of specific interaction energies. In addition, the $\mathrm{n}$ values that were found from fitting of the experimental data to the Freundlich model, are larger than 1, indicating that adsorption corresponds to a physical process. This observation is supported by the fitted $b$ values $<8 \mathrm{~kJ} \mathrm{~mol}^{-1}$ obtained from the Temkin model, which are characterized by a physical adsorption processes, that results from van der Waals type weak interactions [52]. The weak physical nature of the interaction of MB with the OP, AHOP, or AZOP-550 adsorbent materials, is further supported by the $\mathrm{E}$ value (average adsorption energy) obtained from the Dubinin-Radushkevich model $\left(\mathrm{E}<8 \mathrm{~kJ} \mathrm{~mol}^{-1}\right)$ [53].

\subsection{Adsorption Mechanism}

Figure 5 shows the spectra of MB before and after adsorption on OP, AHOP, and AZOP-550. The characteristic bands of methylene blue are: $1594 \mathrm{~cm}^{-1}$, which corresponds to the vibration of $\mathrm{C}-\mathrm{N}$ at $1487 \mathrm{~cm}^{-1}$, related to the $\mathrm{C}-\mathrm{C}$ bond of the aromatic ring, $1390 \mathrm{~cm}^{-1}$, associated to the vibration of $\mathrm{C}-\mathrm{N}$ in the $-\mathrm{N}\left(\mathrm{CH}_{3}\right)_{2}{ }^{+}$group, $1331 \mathrm{~cm}^{-1}$, related to the $-\mathrm{CH}_{3}$ group and $879 \mathrm{~cm}^{-1}$ corresponding to the $\mathrm{C}-\mathrm{H}$ bond in the aromatic ring [54]. After MB adsorption, shifts in the IR bands are observed. For instance, in OP and AHOP adsorbents, the band at $1605 \mathrm{~cm}^{-1}$ shifts to $1594 \mathrm{~cm}^{-1}(\mathrm{C}-\mathrm{N})$, the band at $1484 \mathrm{~cm}^{-1}$ is slightly displaced to $1487 \mathrm{~cm}^{-1}(\mathrm{C}-\mathrm{C})$, and the signal at $890 \mathrm{~cm}^{-1}$ shifts to $879 \mathrm{~cm}^{-1}(\mathrm{C}-\mathrm{H})$. While these shifts may reflect $\pi-\pi$ interactions in the adsorption process, electrostatic interactions should be reflected by the shift of the band (from 1402 to $1390 \mathrm{~cm}^{-1}$ ) which is associated to the functional group containing the positively charged $\mathrm{N}$ as well as by the symmetrical deformation of $-\mathrm{CH}_{3}$ which shifts from 1323 to $1331 \mathrm{~cm}^{-1}$ [55]. For AZOP-550, IR band shifts of the C-N and C-C bonds of the aromatic rings (from 1574 and $1470 \mathrm{~cm}^{-1}$ to 1594 and $1487 \mathrm{~cm}^{-1}$, respectively) suggest that the main dye adsorption force for this substrate, corresponds to $\pi-\pi$ interactions. 


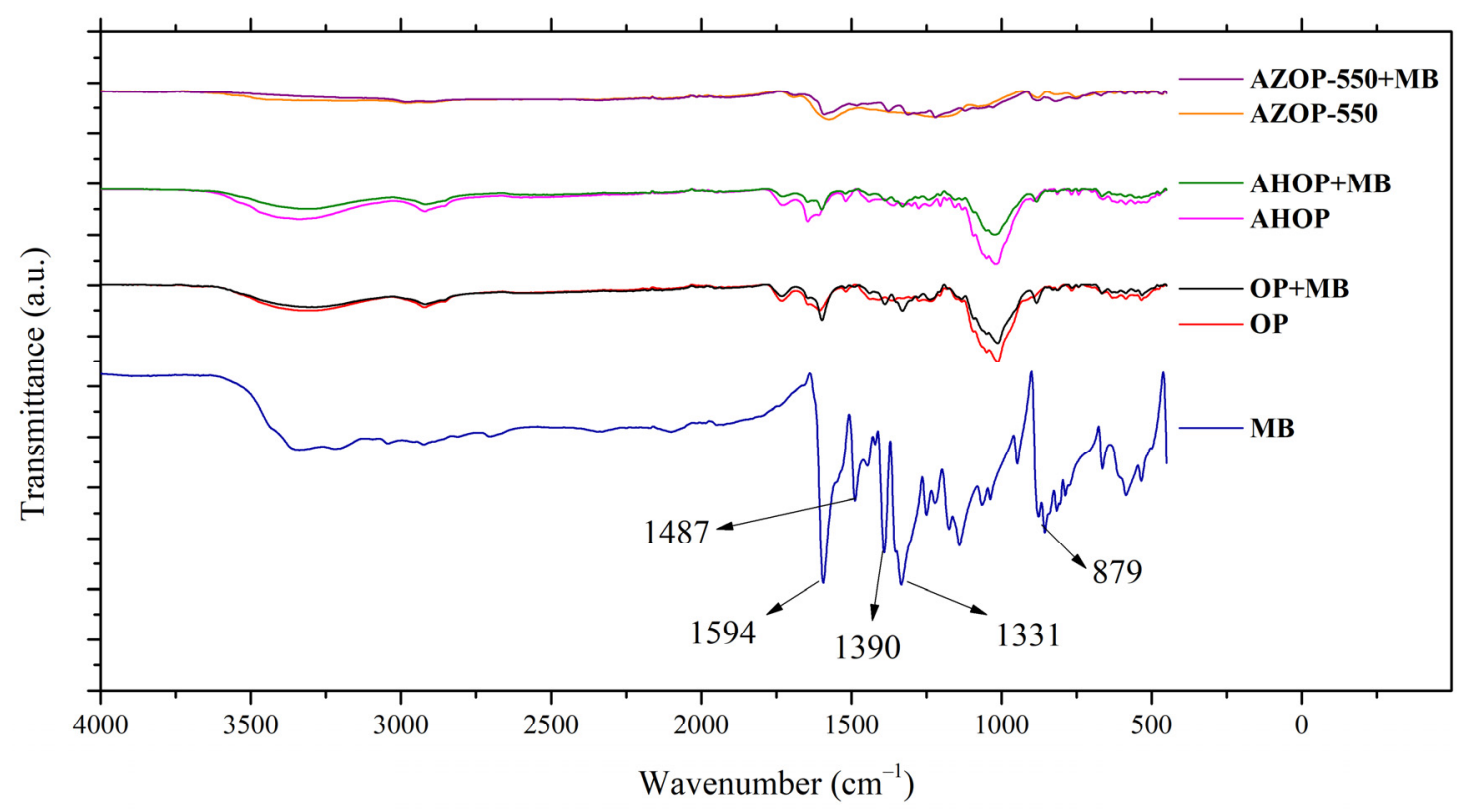

Figure 5. FTIR Spectra of the biochar materials under study before and after MB adsorption.

From the analysis of the experimental data previously discussed, it is possible to suggest that $\mathrm{MB}$ adsorption on OP, AHOP, and AZOP-550 is taking place by a mixture of the following interactions: (i) hydrogen bonds (interaction between the $\mathrm{N}$ (nitrogen) of the $\mathrm{MB}$ structure and an $\mathrm{OH}$ group on the surface of the adsorbent material), (ii) $\pi$ $\pi$ interactions between the aromatic structure of the material and the benzenic rings of $\mathrm{MB}$, and iii) electrostatic interactions, which are presented at $\mathrm{pH}>4$, that is, above the $\mathrm{pH}_{\mathrm{pzc}}$ of the materials and the $\mathrm{pKa}$ of the dye, the MB dye is a cationic species capable of interacting with the negatively charged surface of OP and AHOP (for AZOP-550, surface deprotonation takes at $\mathrm{pH}$ values higher than 6.3). These observations are consistent with previous studies on MB adsorption on the surface of different adsorbents produced from biomass $[4,10,45]$, Figure 6 shows a schematic representation of the interactions that should be taking place during the $\mathrm{MB}$ adsorption event.
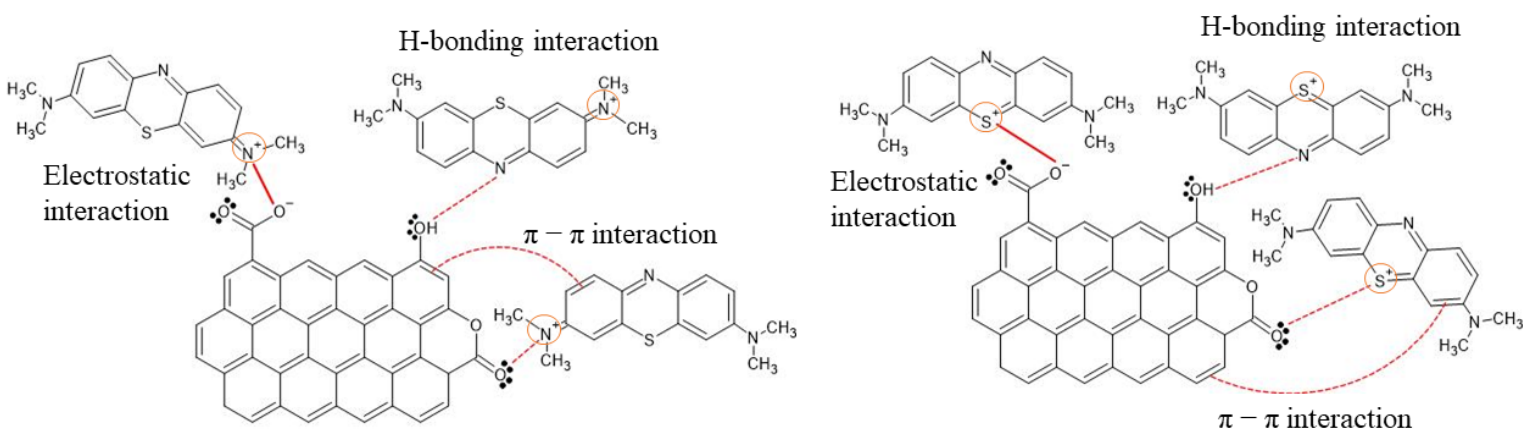

Figure 6. Scheme of the adsorption interactions of MB on biochar materials.

The characterization of the interactions between $\mathrm{MB}^{+}$and the adsorbent materials, was carried out through theoretical calculations. As it was previously discussed, in this work, three adsorption mechanisms have been considered: (i) $\pi-\pi$ stacking interactions, (ii) electrostatic interactions, and (iii) surface complexation reactions (H-bonding) with the chemical moiety (amino) of $\mathrm{MB}^{+}$and the $(-\mathrm{OH})$ group on the adsorbent surface. Figure 7 shows visual illustrations of these interactions and the corresponding adsorption energies are provided in Table 4. 


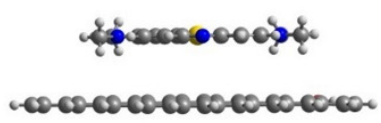

Pristine $\pi-\pi$

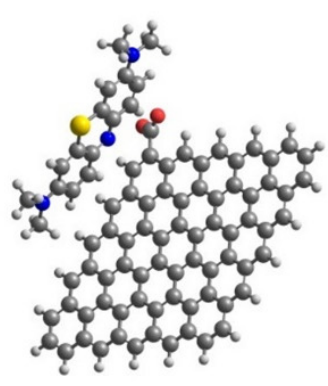

Carboxylate

electrostatic $-\mathbf{m} 1$

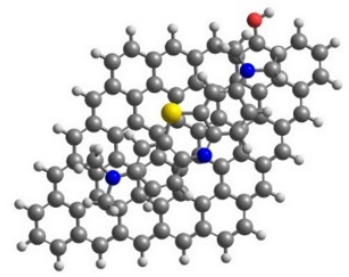

Phenol $\pi-\pi$

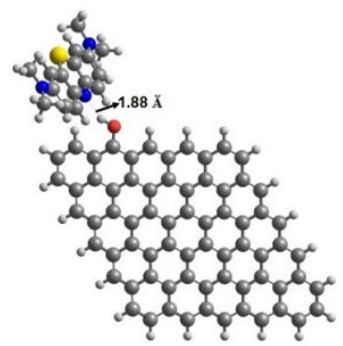

Phenol H-bonding

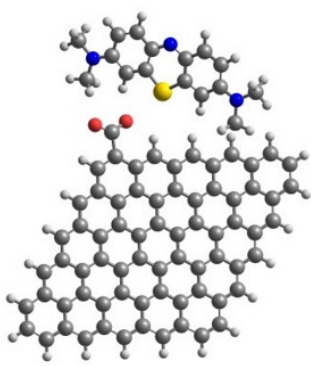

Carboxylate

electrostatic - $\mathbf{m} 2$

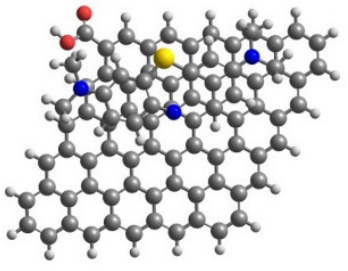

Carboxylic $\pi-\pi$

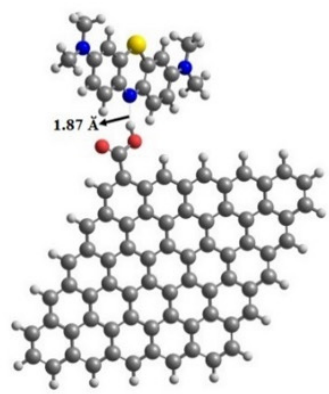

Carboxylic H-bonding

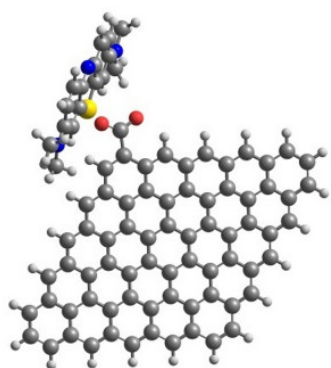

Carboxylate

electrostatic - m3

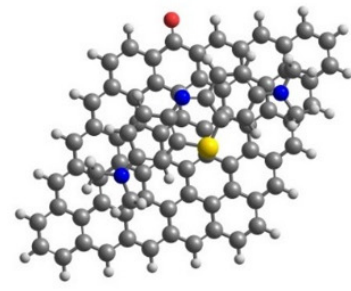

ketone $\pi-\pi$

Figure 7. The optimized structures of $\mathrm{MB}^{+}$adsorption on oxygenated and pristine carbon surfaces.

Table 4. Adsorption energy values $\left(\mathrm{kcal} \mathrm{mol}^{-1}\right)$ for the interactions between methylene blue with a pristine carbon surface and different oxygen functional groups. (The total energy (Hartree) of all systems are presented in the Table S5.).

\begin{tabular}{|c|c|c|c|c|c|}
\hline \multirow[b]{2}{*}{ Interactions } & \multirow[b]{2}{*}{ Pristine } & \multicolumn{4}{|c|}{ Functional Groups } \\
\hline & & $\begin{array}{l}\text { Phenol } \\
\text { (-OH) }\end{array}$ & $\begin{array}{c}\text { Carboxylate } \\
\left(-\mathrm{COO}^{-}\right)\end{array}$ & $\begin{array}{c}\text { Carboxylic } \\
\text { (-COOH) }\end{array}$ & $\begin{array}{c}\text { Ketone } \\
(-\mathrm{CO})\end{array}$ \\
\hline & \multicolumn{5}{|c|}{ Adsorption Energy (kcal mol ${ }^{-1}$ ) } \\
\hline $\begin{array}{c}(\pi-\pi) \\
\text { (H-bonding) }\end{array}$ & 0.20 & $\begin{array}{l}-0.50 \\
-5.76\end{array}$ & & $\begin{array}{l}-0.25 \\
-6.44\end{array}$ & 1.61 \\
\hline Electrostatic & & & $\begin{array}{l}-3.60(\mathrm{~m} 1) \\
-8.46(\mathrm{~m} 2) \\
-8.08(\mathrm{~m} 3) \\
-7.95(\mathrm{~m} 4)\end{array}$ & & \\
\hline
\end{tabular}

From these results, it can be concluded that: (i) in all cases, an adsorbent surface containing oxygenated functional groups is characterized by higher adsorption energies with $\mathrm{MB}$ than a surface without these functional groups, (the ketone group constitutes an exception); (ii) the aromatic rings of $\mathrm{MB}+$ favor $\pi-\pi$ stacking interactions, (iii) strong $\mathrm{MB}^{+}$-carbon surface interactions are due to electrostatic effects while weak $\mathrm{MB}^{+}$-carbon 
surface interactions are due to $\pi-\pi$ stacking phenomena, (iv) the sequence of maximum adsorption energy is electrostatic $(-8.46 \mathrm{kcal} / \mathrm{mol})>\mathrm{H}$-bonding $(-6.44 \mathrm{kcal} / \mathrm{mol})>\pi-\pi$ stacking interactions $(-0.50 \mathrm{kcal} / \mathrm{mol})$. This agrees with the experimental results, where it was found that at $\mathrm{pH}$ values above the $\mathrm{pH}_{\mathrm{pzc}}$, the surface is negatively charged and therefore, the highest adsorption of $\mathrm{MB}^{+}$takes place.

On the other hand, AZOP-550 may be characterized by adsorption from diffusion in the pores of the adsorbent due to the high surface area of this material $\left(1078.56 \mathrm{~m}^{2} \mathrm{~g}^{-1}\right)$. This interpretation is supported by the higher $R^{2}$ value obtained from fitting the experimental data to the intraparticular diffusion model for AZOP-550 when compared to the values computed for $\mathrm{OP}$ and $\mathrm{AHOP}$.

\subsection{Comparison with Other Adsorbents}

Table 5 shows the comparison of the maximum adsorption capacity $\left(\mathrm{Q}_{\mathrm{m}}\right)$ of $\mathrm{MB}$ on $\mathrm{OP}$, AHOP, and AZOP-550 with some recent reports dealing with OP-based adsorbent materials. Inspection of the content of Table 5 shows that residues from orange peel have a great potential to produce efficient adsorbent materials for $\mathrm{MB}$ removal in aqueous solutions. The adsorbents used in this work were produced using simple methodologies, which implies low costs in their production. It was also reported that the orange peel without any transformation has potential for application in water. Therefore, the adsorbents reported in this work can become a cost-effective alternative for reducing MB by adsorption.

Table 5. Comparison of maximum adsorption capacities of MB on different adsorbents.

\begin{tabular}{|c|c|c|c|c|}
\hline Material & Treatment & $\mathrm{pH}$ & $Q_{m}\left(m g g^{-1}\right)$ & Reference \\
\hline $\mathrm{OP}$ & Washed biomass & pH natural (4.5) & 192.31 & This study \\
\hline AZOP-550 & Thermochemical activation using $\mathrm{ZnCl}_{2}\left(550^{\circ} \mathrm{C}\right)$ & pH natural (7.5) & 232.56 & This study \\
\hline AHOP & Chemical activation using $\mathrm{H}_{3} \mathrm{PO}_{4}$ & pH natural (3.7) & 277.78 & This study \\
\hline $\mathrm{ZnCl}_{2}-\mathrm{AC}$ & Thermochemical activation using $\mathrm{ZnCl}_{2}\left(800^{\circ} \mathrm{C}\right)$ & $7-8$ & 281.52 & [24] \\
\hline OP & Washed biomass & 4 & 14.16 & [21] \\
\hline SOP & Chemical activation using $\mathrm{NaOH}$ & 9 & 18.28 & [21] \\
\hline OP & Washed biomass & pH natural (4.2) & 218 & [19] \\
\hline $\mathrm{OP}-\mathrm{H}_{3} \mathrm{PO}_{4}$ & Chemical activation using $\mathrm{H}_{3} \mathrm{PO}_{4}$ & pH natural (6.2) & 307.63 & [51] \\
\hline $\mathrm{COP} 400^{\circ} \mathrm{C}$ & Calcination a $400^{\circ} \mathrm{C}$ & 4.98 & 14.85 & [18] \\
\hline $\mathrm{OP}-\mathrm{ZnCl}_{2}$ & Chemical activation using $\mathrm{ZnCl}_{2}$ & 9 & 7.57 & {$[20]$} \\
\hline
\end{tabular}

\section{Conclusions}

The results found in this study show that by using different transformations, it is not only possible to obtain adsorbent materials from orange peel residues, but that these materials are effective for $\mathrm{MB}$ removal. The existence of oxygenated surface functional groups on the obtained adsorbents (such as $-\mathrm{OH},-\mathrm{COO}^{-},-\mathrm{COOH}$, and $-\mathrm{CO}$ ) allows for specific $\mathrm{pH}$ values that guarantee the deprotonation of surface oxygenated groups by interactions with the cationic dye $\mathrm{MB}$ in aqueous solution. This effect is compensated with large adsorbent areas that can be obtained by thermochemical treatment to generate partially oxygenated adsorbent biochar. The kinetic and isothermal parameters on the other hand, allowed one to conclude that the adsorption process involves a mixture of both physical and chemical interactions, obtaining high adsorption capabilities for MB. Based on DFT calculations and FTIR analysis before and after MB adsorption, it can be concluded that the main mechanisms that exist in the dye adsorption process on the different adsorbent materials are: (i) electrostatic interaction between the positive charge of the MB molecule and the negative charge of the adsorbent surface due to oxygenated functional groups; (ii) surface complexation reactions (H-bonding) among the functionality (amino) of the $\mathrm{MB}^{+}$with $(-\mathrm{OH})$ of the oxygenated groups on carbon surface, and (iii) $\pi$ $(\mathrm{MB})-\pi$ (biochar) interactions. 
Supplementary Materials: The following are available online. Figure S1 FTIR spectra of calcined materials at different temperatures. Figure S2 pH PZC of adsorbent materials. A: OP; B: AZOP-550; C: AHOP. Figure S3 Graphs of the adsorbents (OP, AHOP and AZOP-550) for kinetic models with the equation (C0 $50 \mathrm{mg} \mathrm{L}^{-1}$ ). Figure S4 Graphs of the adsorbents (OP, AHOP and AZOP-550) for isotherm models with the equation. Table S1 Equation kinetic models. Table S2 Equations models isotherms. Table S3 Biomass analysis data. Table S4 Parameters for the different kinetic models for the adsorption of MB on OP, AZOP-550 and AHOP. Table S5. Total energy (Hartree) of all systems

Author Contributions: Conceptualization, S.G., I.R., and E.F.; Data curation, S.G.; Formal analysis, S.G. and N.A.; Funding acquisition, N.A. and E.F.; Investigation, S.G., I.R., L.A.G., and N.A.; Methodology, S.G., N.A., and E.F.; Project administration, N.A.; Resources, N.A. and E.F.; Software, E.F.; Supervision, L.A.G., N.A., and E.F.; Validation, N.A.; Visualization, I.R., L.A.G., and E.F.; Writingoriginal draft, S.G.; Writing—review \& editing, I.R., N.A., and E.F. All authors have read and agreed to the published version of the manuscript.

Funding: The authors acknowledge Universidad de Medellín for financing the project and the support provided by MINCIENCIAS COLOMBIA (before named COLCIENCIAS) through the project No. 120677757983, CT-648-2018 and, CONACyT, Mexico (Grant No. CB-2019-01-285309).

Institutional Review Board Statement: Not applicable.

Informed Consent Statement: Not applicable.

Data Availability Statement: The datasets used and/or analyzed during the current study are available from the corresponding author on reasonable request.

Acknowledgments: The authors from Universidad de Medellín acknowledge the support provided by MINCIENCIAS COLOMBIA (before named COLCIENCIAS) and CENIPALMA through the project No. 120677757983, CT-648-2018. I.R. and L.A.G. also thank CONACyT, Mexico, for financial support trough project CB-2019-01-285309.

Conflicts of Interest: The authors declare no conflict of interest.

\section{References}

1. Fan, S.; Wang, Y.; Wang, Z.; Tang, J.; Tang, J.; Li, X. Removal of methylene blue from aqueous solution by sewage sludge-derived biochar: Adsorption kinetics, equilibrium, thermodynamics and mechanism. J. Environ. Chem. Eng. 2017, 5, 601-611. [CrossRef]

2. Qian, W.; Luo, X.; Wang, X.; Guo, M.; Li, B. Ecotoxicology and Environmental Safety Removal of methylene blue from aqueous solution by modi fi ed bamboo hydrochar. Ecotoxicol. Environ. Saf. 2018, 157, 300-306. [CrossRef] [PubMed]

3. Fu, J.; Xu, Z.; Li, Q.-S.; Chen, S.; An, S.-Q.; Zeng, Q.-F.; Zhu, H.-L. Treatment of simulated wastewater containing Reactive Red 195 by zero-valent iron/activated carbon combined with microwave discharge electrodeless lamp/sodium hypochlorite. J. Environ. Sci. 2010, 22, 512-518. [CrossRef]

4. Fan, S.; Tang, J.; Wang, Y.; Li, H.; Zhang, H.; Tang, J.; Wang, Z.; Li, X. Biochar prepared from co-pyrolysis of municipal sewage sludge and tea waste for the adsorption of methylene blue from aqueous solutions: Kinetics, isotherm, thermodynamic and mechanism. J. Mol. Liq. 2016, 220, 432-441. [CrossRef]

5. Huan, Y. Acrylic acid grafted-multi-walled carbon nanotubes and their high-efficiency adsorption of methylene blue. J. Mater. Sci. 2019. [CrossRef]

6. Nguyen, C.H.; Fu, C.C.; Juang, R.S. Degradation of methylene blue and methyl orange by palladium-doped $\mathrm{TiO}_{2}$ photocatalysis for water reuse: Efficiency and degradation pathways. J. Clean. Prod. 2018, 202, 413-427. [CrossRef]

7. Ali, S.A.; Yaagoob, I.Y.; Mazumder, M.A.J.; Al-Muallem, H.A. Fast removal of methylene blue and Hg(II) from aqueous solution using a novel super-adsorbent containing residues of glycine and maleic acid. J. Hazard. Mater. 2019, 369, 642-654. [CrossRef]

8. Yang, Z.; Chai, Y.; Zeng, L.; Gao, Z.; Zhang, J.; Ji, H. Effcient removal of copper ion from waste water using a stable chitosan gel material. Molecules 2019, 24, 4205. [CrossRef]

9. Giraldo, S.; Ramirez, A.P.; Ulloa, M.; Flórez, E.; Acelas, N.Y. Dyes removal from water using low cost absorbents. J. Phys. Conf. Ser. 2017, 935. [CrossRef]

10. Siddiqui, S.I.; Zohra, F.; Chaudhry, S.A. Nigella sativa seed based nanohybrid composite- $\mathrm{Fe}_{2} \mathrm{O}_{3}-\mathrm{SnO}_{2} / \mathrm{BC}$ : A novel material for enhanced adsorptive removal of methylene blue from water. Environ. Res. 2019, 178, 108667. [CrossRef]

11. Ramírez Muñoz, A.P.; Giraldo, S.; Flórez Yepes, E.; Acelas Soto, N.Y. Preparación de carbón activado a partir de residuos de palma de aceite y su aplicación para la remoción de colorantes. Rev. Colomb. Química 2017, 46, 33-41. [CrossRef]

12. Benitez Monsalve, N. Con Cáscaras de Naranja, Quieren Mejorar la Industria y el Ambiente Colombiano. Available online: https: / / www.laopinion.com.co/economia/con-cascaras-de-naranja-quieren-mejorar-la-industria-y-el-ambiente-colombiano108367\#OP (accessed on 17 June 2021). 
13. Kebaili, M.; Djellali, S.; Radjai, M.; Drouiche, N.; Lounici, H. Valorization of orange industry residues to form a natural coagulant and adsorbent. J. Ind. Eng. Chem. 2018, 64, 292-299. [CrossRef]

14. Ahmadpour, A.; Zabihi, M.; Bastami, T.R.; Tahmasbi, M.; Ayati, A. Rapid removal of mercury ion (II) from aqueous solution by chemically activated eggplant hull adsorbent. J. Appl. Res. Water Wastewater 2016, 6, 236-240.

15. Ahmad, M.; Lee, S.S.; Dou, X.; Mohan, D.; Sung, J.K.; Yang, J.E.; Ok, Y.S. Effects of pyrolysis temperature on soybean stover- and peanut shell-derived biochar properties and TCE adsorption in water. Bioresour. Technol. 2012, 118, 536-544. [CrossRef]

16. Giraldo, S.; Robles, I.; Ramirez, A.; Flórez, E.; Acelas, N. Mercury removal from wastewater using agroindustrial waste adsorbents. SN Appl. Sci. 2020, 2, 1029. [CrossRef]

17. Danish, M.; Hashim, R.; Ibrahim, M.N.M.; Sulaiman, O. Effect of acidic activating agents on surface area and surface functional groups of activated carbons produced from Acacia mangium wood. J. Anal. Appl. Pyrolysis 2013, 104, 418-425. [CrossRef]

18. Khalfaoui, A.; Bendjamaa, I.; Bensid, T.; Meniai, A.H.; Derba, K. Effect of calcination on orange peels characteristics: Application of an industrial dye adsorption. Chem. Eng. Trans. 2014, 38, 361-366. [CrossRef]

19. Boumediene, M.; Benaïssa, H.; George, B.; Molina, S.; Merlin, A. Characterization of two cellulosic waste materials (orange and almond peels) and their use for the removal of methylene blue from aqueous solutions. Maderas. Cienc. Tecnol. 2015, 17, 69-84. [CrossRef]

20. Andreas, A.; Reinaldo, J.; Tertira, K. A Study on The Adsorption Equilibrium and Kinetics of Methylene Blue onto Orange Peel Wastes as Biosorbents. In Proceedings of the 2016 2nd International Conference of Industrial, Mechanical, Electrical, and Chemical Engineering (ICIMECE), Yogyakarta, Indonesia, 6-7 October 2016; pp. 59-62.

21. Salman, T.A.; Ali, M.I. Potential Application of Natural and Modified Orange Peel as an Eco-friendly Adsorbent for Methylene Blue Dye. Iraqi J. Sci. 2016, 57, 1-13.

22. Fernandez, M.E.; Nunell, G.V.; Bonelli, P.R.; Cukierman, A.L. Activated carbon developed from orange peels: Batch and dynamic competitive adsorption of basic dyes. Ind. Crop. Prod. J. 2014, 62, 437-445. [CrossRef]

23. Amin, M.T.; Alazba, A.A.; Shafiq, M. Comparative study for adsorption of methylene blue dye on biochar derived from orange peel and banana biomass in aqueous solutions. Environ. Monit. Assess. 2019, 191, 735. [CrossRef] [PubMed]

24. Bediako, J.K.; Lin, S.; Sarkar, A.K.; Zhao, Y.; Choi, J.; Song, M.; Cho, C.; Yun, Y. Evaluation of orange peel-derived activated carbons for treatment of dye-contaminated wastewater tailings. Environ. Sci. Pollut. Res. 2020, 27, 1053-1068. [CrossRef] [PubMed]

25. Santoso, E.; Ediati, R.; Kusumawati, Y.; Bahruji, H.; Sulistiono, D.O.; Prasetyoko, D. Review on recent advances of carbon based adsorbent for methylene blue removal from waste water. Mater. Today Chem. 2020, 16, 100233. [CrossRef]

26. Franca, A.S.; Oliveira, L.S.; Ferreira, M.E. Kinetics and equilibrium studies of methylene blue adsorption by spent coffee grounds. Desalination 2009, 249, 267-272. [CrossRef]

27. Agarwal, S.; Tyagi, I.; Kumar, V.; Ghasemi, N.; Shahivand, M.; Ghasemi, M. Kinetics, equilibrium studies and thermodynamics of methylene blue adsorption on Ephedra strobilacea saw dust and modified using phosphoric acid and zinc chloride. J. Mol. Liq. 2016, 218, 208-218. [CrossRef]

28. Achour, Y.; Khouili, M.; Abderrafia, H.; Melliani, S.; Laamari, M.R.; El Haddad, M. DFT Investigations and Experimental Studies for Competitive and Adsorptive Removal of Two Cationic Dyes onto an Eco-friendly Material from Aqueous Media. Int. J. Environ. Res. 2018, 12, 789-802. [CrossRef]

29. Sellaoui, L.; Franco, D.; Ghalla, H.; Georgin, J.; Netto, M.S.; Luiz Dotto, G.; Bonilla-Petriciolet, A.; Belmabrouk, H.; Bajahzar, A. Insights of the adsorption mechanism of methylene blue on brazilian berries seeds: Experiments, phenomenological modelling and DFT calculations. Chem. Eng. J. 2020, 394, 125011. [CrossRef]

30. Tovar, A.K.; Godínez, L.A.; Espejel, F.; Ramírez-Zamora, R.-M.; Robles, I. Optimization of the integral valorization process for orange peel waste using a design of experiments approach: Production of high-quality pectin and activated carbon. Waste Manag. 2019, 85, 202-213. [CrossRef] [PubMed]

31. Bakatula, E.N.; Richard, D.; Neculita, C.M.; Zagury, G.J. Determination of point of zero charge of natural organic materials. Environ. Sci. Pollut. Res. 2018, 25, 7823-7833. [CrossRef]

32. Goertzen, S.L.; Thériault, K.D.; Oickle, A.M.; Tarasuk, A.C.; Andreas, H.A. Standardization of the Boehm titration. Part I. CO 2 expulsion and endpoint determination. Carbon N. Y. 2010, 48, 1252-1261. [CrossRef]

33. Ramirez, A.; Ocampo, R.; Giraldo, S.; Padilla, E.; Flórez, E.; Acelas, N. Removal of Cr (VI) from an aqueous solution using an activated carbon obtained from teakwood sawdust: Kinetics, equilibrium, and density functional theory calculations. J. Environ. Chem. Eng. 2020, 8, 103702. [CrossRef]

34. Isah, U.A.; Abdulraheem, G.; Bala, S.; Muhammad, S.; Abdullahi, M. Kinetics, equilibrium and thermodynamics studies of C.I. Reactive Blue 19 dye adsorption on coconut shell based activated carbon. Int. Biodeterior. Biodegradation 2015, 102, $265-273$. [CrossRef]

35. Acelas, N.Y.; Martin, B.D.; López, D.; Jefferson, B. Selective removal of phosphate from wastewater using hydrated metal oxides dispersed within anionic exchange media. Chemosphere 2015, 119, 1353-1360. [CrossRef] [PubMed]

36. Tareq, R.; Akter, N.; Azam, S. Chapter 10-Biochars and Biochar Composites: Low-Cost Adsorbents for Environmental Remediation. Biochar Biomass Waste 2019, 169-210. [CrossRef]

37. Freundlich, H. Über die adsorption in lösungen. Z. Phys. Chem. 1907, 57, 385-470. [CrossRef] 
38. Langmuir, I. The adsorption of gases on plane surfaces of glass, mica and platinum. J. Am. Chem. Soc. 1918, 40, 1361-1403. [CrossRef]

39. Temkin, M.J.; Pyzhev, V. Recent modifications to Langmuir isotherms. Acta Physicochim. URSS 1940, 12, $217-222$.

40. Foo, K.Y.; Hameed, B.H. Insights into the modeling of adsorption isotherm systems. Chem. Eng. J. 2010, 156, 2-10. [CrossRef]

41. Frisch, M.; Trucks, G.; Schlegel, H.; Scuseria, G.; Robb, M.; Cheeseman, J.; Scalmani, G.; Barone, V.; Petersson, G.; Nakatsuji, H.; et al. Gaussian 09; Revision A.02; University of Cincinnati Libraries: Wallingford, CT, USA, 2009.

42. Keith, T.A.; Frisch, M.J. Inclusion of Explicit Solvent Molecules in a Self-Consistent-Reaction Field Model of Solvation. In Modeling the Hydrogen Bond; ACS Symposium Series; American Chemical Society: Washington, DC, USA, 1994; Volume 569, pp. 22-35. ISBN 9780841229815.

43. Li, Z.; Hanafy, H.; Zhang, L.; Sellaoui, L.; Schadeck, M.; Oliveira, M.L.S.; Seliem, M.K.; Luiz, G.; Bonilla-petriciolet, A. Adsorption of congo red and methylene blue dyes on an ashitaba waste and a walnut shell-based activated carbon from aqueous solutions: Experiments, characterization and physical interpretations. Chem. Eng. J. 2020, 388, 124263. [CrossRef]

44. Shakoor, S.; Nasar, A. Removal of methylene blue dye from artificially contaminated water using citrus limetta peel waste as a very low cost adsorbent. J. Taiwan Inst. Chem. Eng. 2016, 66, 154-163. [CrossRef]

45. Gayathri, K.; Palanisamy, N. Methylene blue adsorption onto an eco-friendly modified polyacrylamide/graphite composites: Investigation of kinetics, equilibrium, and thermodynamic studies. Sep. Sci. Technol. 2020, 55, 1-12. [CrossRef]

46. Thi, H.T.; Le, A.H.; Huu, T.P.; Dinhd, T.N.; Chang, S.W.; Chung, W.J.; Nguyen, D.D. Adsorption isotherms and kinetic modeling of methylene blue dye onto a carbonaceous hydrochar adsorbent derived from coffee husk waste. Sci. Total Environ. 2020, 725, 138325. [CrossRef]

47. Guimarães Gusmão, K.A.; Alves Gurgel, L.V.; Sacramento Melo, T.M.; Frédéric Gil, L. Adsorption studies of methylene blue and gentian violet on sugarcane bagasse modified with EDTA dianhydride (EDTAD) in aqueous solutions: Kinetic and equilibrium aspects. J. Environ. Manag. 2013, 118, 135-143. [CrossRef] [PubMed]

48. Salazar-rabago, J.J.; Leyva-ramos, R.; Rivera-utrilla, J.; Ocampo-perez, R.; Cerino-cordova, F.J. Biosorption mechanism of Methylene Blue from aqueous solution onto White Pine (Pinus durangensis) sawdust: Effect of operating conditions. Sustain. Environ. Res. 2017, 27, 32-40. [CrossRef]

49. Rodrigues Sousa, H.; Santos Silva, L.; Abreu Sousa, P.A.; Magalhães Sousa, R.R.; Gardênnia Fonseca, M.; Anteveli Osajima, J.; Silva-Filho, E.C. Evaluation of methylene blue removal by plasma activated palygorskites. J. Mater. Res. Technol. 2019, 8, 5432-5442. [CrossRef]

50. Boumediene, M.; Benaïssa, H.; George, B.; Molina, S.; Merlin, A. Effects of $\mathrm{pH}$ and ionic strength on methylene blue removal from synthetic aqueous solutions by sorption onto orange peel and desorption study. J. Mater. Environ. Sci. 2018, 9, $1700-1711$. [CrossRef]

51. Guediri, A.; Bouguettoucha, A.; Chebli, D.; Chafai, N.; Amrane, A. Molecular dynamic simulation and DFT computational studies on the adsorption performances of methylene blue in aqueous solutions by orange peel-modified phosphoric acid. J. Mol. Struct. J. 2020, 1202, 1-14. [CrossRef]

52. Zhang, X.; Fu, W.; Yin, Y.; Chen, Z.; Qiu, R.; Simonnot, M.-O.; Wang, X. Adsorption-reduction removal of Cr(VI) by tobacco petiole pyrolytic biochar: Batch experiment, kinetic and mechanism studies. Bioresour. Technol. 2018, 268, 149-157. [CrossRef]

53. Nguyen, H.; You, S.; Hosseini-bandegharaei, A. Mistakes and inconsistencies regarding adsorption of contaminants from aqueous solutions: A critical review. Water Res. 2017, 120, 88-116. [CrossRef]

54. Li, B.; Lv, J.; Guo, J.; Fu, S.; Guo, M.; Yang, P. The polyaminocarboxylated modifed hydrochar for efficient capturing methylene blue and $\mathrm{Cu}$ (II) from water. Bioresour. Technol. 2019, 275, 360-367. [CrossRef]

55. Wu, Z.; Zhong, H.; Yuan, X.; Wang, H.; Wang, L.; Chen, X.; Zeng, G.; Wu, Y. Adsorptive removal of methylene blue by rhamnolipid-functionalized graphene oxide from wastewater. Water Res. 2014, 67, 330-344. [CrossRef] [PubMed] 